\title{
Sto znamenitih osebnosti v šolstvu na Slovenskem
}

\author{
Pavlič, Slavica
}

A

vtorica Slavica Pavlič se je lotila zahtevne naloge, izbire sto osebnosti, pomembnih za razvoj šolstva na Slovenskem. Knjiga, ki je lansko leto izšla pri Prešernovi družbi v Ljubljani, potrjuje, da je bila zahtevna naloga, ki si jo je zastavila, dobro opravljena.

$\mathrm{Z}$ izbiro je avtorica želela opozoriti na tiste pedagoške delavce, ki so bili s svojim delovanjem zaslužni za izboljšanje šolstva na Slovenskem.

Knjiga se začenja z obsežnim uvodom, v katerem je kratek pregled zgodovine šolstva na

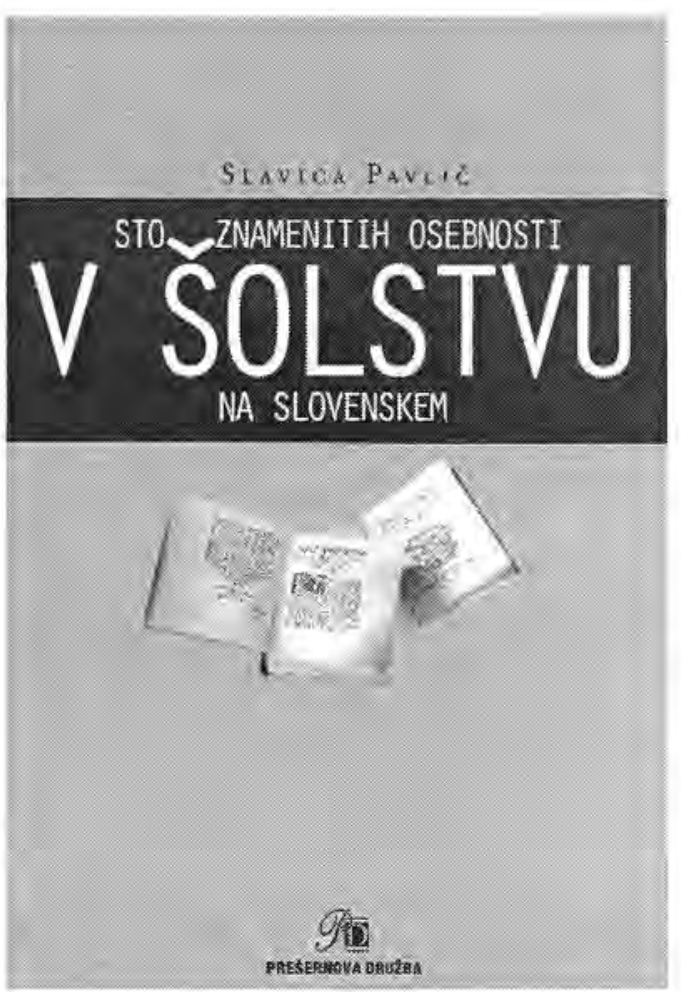

Slovenskem. Vanj je vključen tudi zgodovinski pregled izobraževanja slovenskega učiteljstva in razvoj osnovne šole na Slovenskem.

Izbira znamenitih osebnosti seže $v$ 16. stoletje, začenši s Primožem Trubarjem. Nadaljuje se skozi vsa kasnejša zgodovinska obdobja $\mathrm{v}$ pozno 20, stoletje. V izbiri so zajeti vsi, ki so imeli pomembno vlogo pri razvoju šolstva na Sloven- skem. Naj omenimo le nekatere: Blaž Kumerdej, pomemben $\mathrm{v}$ zvezi z zahtevami po osnovni šoli v maternem jeziku, Anton Tomaž Linhart, ki je pripomogel $\mathrm{k}$ ustanovitvi več šol na Kranjskem, Valentin Vodnik kot ravnatelj ljubljanske ljudske šole in gimnazije, Janoš Kardoš kot eden izmed nosilcev izobraževanja v Prekmurju, Karel Robida kot avtor prvega učbenika za fiziko v slovenskem jeziku, Henrik Schreiner kot ustanovitelj Slovenske šolske matice, Janja Miklavčič kot aktivistka pri Društvu slovenskih učiteljic, pa Karel Ozvald, Engelbert Gangl, Eliza Kukovec, Franjo Žgeč, Iva Šegula, Helena Puhar, Vlado Schmidt, Rudi Lešnik ..., z Romanom Oberlintnerjem na koncu, ki si je prizadeval za izenačitev možnosti vključitve vseh otrok v izobraževanje.

Avtorica je predstavitve pomembnih pedagogov opremila $\mathrm{z}$ njihovimi fotografijami in drugim slikovnim gradivom. Temu je dodala še povzetek njihovih zaslug pri razvoju šolstva na Slovenskem. To pripomore $\mathrm{k}$ večji preglednosti knjige, ki že nenatančnemu in naključnemu bralcu omogoča vpogled $\mathrm{v}$ bistvo posameznikovega prizadevanja.

Knjiga je pomemben prispevek $\mathrm{k}$ pregledu razvoja pedagogike in šolstva na Slovenskem in bo gotovo koristen pripomoček ne samo študentom pri poglabljanju zgodovinskega znanja, temveč zanimivo branje za vse, ki niso ravnodušni do razvoja nacionalnega šolstva.

Tanja Šulak 